\title{
Analysis of the Relationship between the Dimensions of the Old Urban Tissue and Social Security, Case Study: Region 15 of Tehran
}

\author{
1Gholamreza Soroushan
}

\begin{abstract}
${ }^{2}$ Alireza Estelaji
3Parvaneh Zivyar

${ }^{1}$ Department of geography, college of human sciences, Yadegar - e- Imam Khomeini (rah), Shahre-Rey Branch, Tehran, Iran ${ }^{2}$ Department of geography, college of human sciences, Yadegar - e- Imam Khomeini (rah), Shahre-Rey Branch, Tehran, Iran ${ }^{3}$ Department of geography, college of human sciences, Yadegar - e- Imam Khomeini (rah), Shahre-Rey Branch, Tehran, Iran Correspondence: gholamreza soroushan, Tehran, Iran,Email:surushan123@gmail.com
\end{abstract}

\author{
Doi:10.5901/ajis.2016.v5n2p53
}

Abstract

Today, Social Security, one of the main needs of citizens at all ages and genders and this is even more important for older residents, as the experiences of everyday life in inefficient spaces that is more insecurity in these areas. This study examines the sense of security in Tehran in the region 15 are damaged. Statistical research, all residents of District 15, which is worn tissue sampling formula 384 were selected. After reading library and review, review of literature required to survey data collected by a questionnaire and using descriptive statistics and inferential statistics (Pearson correlation coefficient $t$ ) were analyzed using SPSS software. The results show that the dimensions of environmental, economic, social, physical and worn tissue management area 15 is not in good condition. The social security situation in the region, 15 in the old context is not appropriate. The study, a significant inverse relationship between two variables worn tissue and a decrease in security. A significance level of less than $05 / 0$ and strong relationship between the two variables shows negative inversely. One of the factors in the decline in security in the context of life in the region 15 Location immigrants, criminals and so on.

Keywords: security, social security, old texture, District 15

\section{Statement of the Problem}

Cities are the most important of civilizations in any society, signs whose antiquity and rigor are symbols of authenticity and stability of their residents. Cities and urban environments are symbols of thoughts, traditions, relationships and communications of people over eons. That's why the older a city is, the more valuable it is considered; people link antiquity of their cities with their identity. A glance at the human cultural heritage all over the world helps us understand that great and famous nations have left behind cities and other great works (Hanachi et al, 2007).

However, these elements and components of urban environment are short-lived and will decay in the passage of time. In other words, no environment and building can last long without being optimized or repaired (Pur Ahmad \& Shamai, 2006). Therefore, development of demolition, lack of enough facilities and equipment, and reduction of the quality of old textures have led to the degradation of social rank of such environments in the view of citizens; the other result is that indigenous people of those districts with enough economic capability move to other districts and are replaced by with poorer people which are more vulnerable to social harms such as addiction.

Therefore, cultural values and feelings of attachment to home, district and city disappear in a way that in some cases urban life is put at risk because as the destruction and inactivity of old textures increases, they turn into suitable places for behavioral deviance and social disorders. The choice of old urban textures for the settlement of immigrants and low-income people is a sign of increase in economic, social and cultural problems which is a threat to the city. Such environments, despite constituting an important part of urban identities and having valuable residential roots witch cultural, social and architectural richness, gradually turned into insecure areas which faced urban identity with problem.

Southern districts such as District 15 of Tehran with more than 200 years' history can be undoubtedly one of the oldest neighborhoods of Tehran and it may also be regarded as one of the neighborhoods playing a key role in all historical events of Tehran, being also the political capital of Iran after Islamic Revolution. These regions are also the core of Tehran in which the city has been formed and they are a part of the valuable texture the solidarity and cohesion of 
which is still intact in the heart of the city. But unfortunately, these neighborhoods, in spite of such cultural richness, have long faced a problem called worn-out texture. The existence of worn-out textures in different parts of Tehran, especially in southern districts of the city have made the discussions about development and renewal in addition to the issues related to physical form at various cultural and social levels more important than ever. Thus, the examination of this issue is of high importance.

Now, regarding the history of urbanism and increasing development of old textures in our country, especially in Tehran, on one hand and its social, economic, professional, legal, managerial and environmental aspects on the other hand, this issue has become one of the most serious and the most important issues in professional circles. This importance has doubled in recent years and has posed different questions to the officials (Andalib, 2008, p. 24).

Now, with all that was said regarding sociocultural problems in old textures, we will investigate social security in old textures of district 15 of Tehran. To this end, the following hypotheses were formulated:

1. It seems that environmental, social and managerial aspects of old textures are not in good condition.

2. The status of social security in old textures of district 15 is not in a suitable level.

3. Today, old textures of district 15 have led to decrease in security.

\section{Theoretical Framework}

\subsection{The quality of urban environment and social security in urban neighborhoods}

The quality of urban environment can be defined as "social. Cultural, economic and special conditions of urban environment that shows the level of citizens' satisfaction or dissatisfaction of urban environment (Shamai \& Pur Ahmad, 2005 , p. 274). Therefore, environmental quality is the result of combinational and continuous parts in a given district which are considered as environmental perception more than any other part. In fact, environmental quality can be regarded as an integral part of extended conception of life quality including such fundamental conceptions as healthcare and security combined with aspects like attractiveness (RIVM, 2002). Crime and security analysis is not an entirely legal or judicial issue; it is rather a geographical, economic, social, cultural and political issue.

Its contributing factors are not similar across societies: they are different from the viewpoint of type of crime, its intensity and its frequency. These differences are easily observable in cities, villages, regions and districts of a city. In any society or environment a set of factors such as environmental conditions, environmental quality, economic situation, etc. are effective in the behavior of its residents. Paying attention to the outcomes of hurried urbanism in recent decades like increased poverty and insecurity, low quality of urban neighbors, insufficient housing services and utility-like sanitary services and water supply-, emergence of slums and illegal housings, destruction of environment and national and local states' inability to find solutions to these problems from one hand, and the importance of acknowledging the role social security plays in successful development programs on the other hand, have increased the importance of environmental quality.

Considering what was said about the mutual relationship of environmental quality and social security, they have quantitative indicators based on which the exact amounts of harms, deviations, abnormalities, crime, felony, addiction and suicide are both considered as indicators of decreased environmental quality and social insecurity in a way that in the analysis of decreased environmental quality and its effect on social insecurity, one can measure the effects of decreased social values and the lack of trust in social relationships on the rise of deviations, harms, abnormalities, crimes, etc. For example, how waning values and norms regarding environmental quality have an increasing effect on robbery, vandalism, assault and different political, administrative, economic and judicial crimes. Knowing this helps us better support one's moral rights; it also results in social regulations which is a pre-requirement for social security.

It is to be noted that some cities have places in which there are more causes for fear like unsuitable lighting, strolling of the homeless and the addict and lack of pavements in the highways. According to Oscar Newman's theory, places where it is possible to clearly see things and where the chance of escaping is low, they are less prone to criminal activities. Therefore, it is suggested that walls, fences and hedges act as physical barriers and increase the sense of insecurity; on the contrary, where there are signs of people's observance this sense increases (Schweitzer, 1977, p. 11).

\subsection{Backgrounds of the study}

Results of a study done by Falahat and Rahim Zadeh (2014) shows that we can create a rather secure and safe place by intervening in the body of the places. Ahmadi (2014) believes that insecurity caused by reasons such as migration, 
lowering of social status, poverty, etc. is among the main indicators of decreased level of life quality. Hosein and Adib Zadeh (2009) have pointed out that old textures in cities due to disregard of physical, economic and social requirements and as a result of disappearing the feeling of attachment to those place, pave the way for the emergence of social harms. Afshari et al (2014) have investigated the role of physical factors in decreasing behavioral abnormalities and crimes; they have also suggested physical criteria by which to create a secure place, prevent behavioral abnormalities and bring security to the old textures in southern Shariati Street in Tabriz.

Findings of a study carried out by Azimi et al (2011) shows that disregarding physical, economic and social requirements in building cities and a detachment with those textures have provided the ground for appearance of different social harms. They state that such cities will be entangled with serious problems and the existence of ruined and abandoned buildings will intensify these problems.

Gholipur et al (2015) have pointed out that historical and cultural importance and sometimes touristic attractions of such quarters on the one hand, and their disproportionality with the necessities of modern life on the other hand have increased the necessity of rebuilding these textures to guarantee security. In the same way, Attaran et al (2014) believe that disregard of such places and detachment of residents with those places have resulted in emergence of social harms. The method of preventing civil crimes with an emphasis on the design is one way of reducing crimes. Arsalani et al (2015) have stated that intervening physical properties of cities is one way of bringing back security. Of course, dominating spirit of any place is far more important than the physicality of that place; it is because of the social communications of those who are linked with each other, i.e. physicality affects behaviors and behaviors, in turn, affect the way physicality is used.

\subsection{Methodology}

This research had been an analytic-descriptive one and data are gathered by questionnaires. The sample population included all the residents of old textures in district 15 out of which 384 persons were chosen by sampling formula. The questionnaire was designed with a view on research questions and theoretical framework and included common options in any statistic studies. Having gathered data, they were analyzed using SPSS software. Pearson correlation coefficient and one-sample t-test were used for the assessment of possible relationships among research variables. Reliability of questionnaire was determined by Cronbach's alpha which equaled to 0.76 . As to the validity of the questionnaire, experts' viewpoints were used.

\subsection{Data description}

Participants were divided into four age groups: 15-30, 31-45, 46-60, and over 60. Out of all participants 174 persons were in the first age group, 130 persons were in the second age group, 57 persons were in the third age group, and 23 persons were in the last one. 221 of participants were male and 173 of participants were female. They were assigned to five different types of occupation: self-employed, employee, student, householder, and unemployed. 153 persons were self-employed, 94 persons were employees, 61 persons were students, 33 persons were householders, and 43 persons were unemployed. 189 persons of all participants were single and 195 persons were married.

Out of all participants of the study 2 persons were illiterate, 3 persons had primary educations, 12 persons had finished middle school, 58 persons had finished high school, 228 persons had associate or bachelor's degree and 74 persons had master's degrees or higher. Citizens' settlement times were divided into five periods: less than 5 years, between 5-10 years, between 10-15 years, between 15-20 years, and more than 20 years. 117 persons had settled there for more than 20 years.

\section{Analysis of Findings}

\subsection{Investigation of environmental aspect in old textures of district 15}

A series of indicators were formulated for the assessment of the effect of old texture on social security in district 15 which were divided into 5 groups: environmental, economic, social, physical, and managerial indicators. As to the analysis of sub-indicators, one-sample t-test was used. Because there is only one variable, one-sample t-test is used. If significance level is less than 0.05 and the mean is higher than normal, $\mathrm{H} 1$ is confirmed; if significance level is more than 0.05 and the mean be lower than normal (3), $\mathrm{HO}$ is confirmed. Results of the analysis of the status of environmental variable are reported in table 1. 
Table 1: Assessment of environmental variable in district 15

\begin{tabular}{|c|c|l|l|l|l|l|l|l|l|}
\hline $\begin{array}{l}\text { Difference in level .39 of } \\
\text { certainty distance }\end{array}$ & $\begin{array}{l}\text { Mean } \\
\text { difference }\end{array}$ & $\begin{array}{l}\text { Significance } \\
\text { level }\end{array}$ & $\begin{array}{l}\text { Degree of } \\
\text { freedom }\end{array}$ & $\begin{array}{l}\text { t-test } \\
\text { statistics }\end{array}$ & $\begin{array}{l}\text { Mean of standard } \\
\text { deviation }\end{array}$ & $\begin{array}{l}\text { Standard } \\
\text { deviation }\end{array}$ & Mean & Variable \\
\hline .49 & .24 & .364 & .000 & 383 & 5.913 & .062 & 1.104 & 3.36 & Sewage \\
\hline .83 & .62 & .723 & .000 & 383 & 13.595 & .053 & .953 & 3.72 & Air pollution \\
\hline .33 & .04 & .184 & .016 & 383 & 2.433 & .076 & 1.353 & 3.18 & Visual pollution \\
\hline .15 & -.13 & .006 & .000 & 383 & .088 & .071 & 1.275 & 3.01 & Sound pollution \\
\hline 1.70 & 1.03 & 1.367 & .000 & 383 & 8.411 & .162 & .890 & 4.37 & Inundation \\
\hline 1.85 & 1.35 & 1.600 & .000 & 383 & 12.990 & .123 & .675 & 4.60 & Trash malodor \\
\hline
\end{tabular}

According to the information of above table, it can be observed that significance levels of all variables are less than 0.05 and are meaningful. The mean of variables are 3.36, 3.72, 3.18, 3.01, 4.37, and 4.60 for Sewage, Air pollution, Visual pollution, Sound pollution, Inundation, and Trash malodor respectively. It means that form the viewpoint of environmental indicators, district 15 is in an adverse situation.

\subsection{Investigation of economic aspect in old textures of district 15}

Unemployment, low income, poverty, value of the ground, changing consumption pattern, unbalanced investment in city development, taxation and tolls and weak cooperation among economic and cultural organization in socioeconomic development of old textures are some problems threatening old textures of cities. A suitable solution should be found to stop the stagnation of these districts. They should be granted a fresh breath be reviving and rebuilding those districts which have lost their dynamism.

Reconstruction of old textures should be in a way that such principles as architecture and urbanization principles, enablement of residents to participate, preventing intervention of dealers, optimum efficiency, rapid reconstruction, having definite, separable and flexible plans, positive points of reconstruction from the economic point of view, optimal use of grounds, and reduction of the distance between two different poles of the city are observed. To this end, four variables are used to analyze economic situation of old textures whose results are presented in the following table.

Table 2: Assessment of changing economic situation in district 15

\begin{tabular}{|c|c|c|c|c|c|c|c|c|c|}
\hline \multicolumn{2}{|c|}{$\begin{array}{l}\text { Difference in level .95 of } \\
\text { certainty distance }\end{array}$} & \multirow[t]{2}{*}{$\begin{array}{l}\text { Mean } \\
\text { difference }\end{array}$} & \multirow[t]{2}{*}{$\begin{array}{l}\text { Significance } \\
\text { level }\end{array}$} & \multirow[t]{2}{*}{$\begin{array}{l}\text { Degree of } \\
\text { freedom }\end{array}$} & \multirow{2}{*}{$\begin{array}{l}\text { t-test } \\
\text { statistics }\end{array}$} & \multirow{2}{*}{$\begin{array}{l}\text { Mean of } \\
\text { standard } \\
\text { deviation }\end{array}$} & \multirow[t]{2}{*}{$\begin{array}{l}\text { Standard } \\
\text { deviation }\end{array}$} & \multirow[t]{2}{*}{ Mean } & \multirow[t]{2}{*}{ Indicators } \\
\hline The highest & The lowest & & & & & & & & \\
\hline .90 & .59 & .741 & .000 & 383 & 9.338 & .079 & 1.423 & 3.74 & Fluctuation and high price of lands \\
\hline .26 & -.09 & .087 & .021 & 383 & .975 & .089 & 1.602 & 3.09 & Fluctuation and high price of homes \\
\hline .29 & .01 & .153 & .002 & 383 & 2.126 & .072 & 1.286 & 3.15 & $\begin{array}{l}\text { The lack of cooperation of government } \\
\text { and citizens in investment }\end{array}$ \\
\hline .32 & .03 & .178 & .000 & 383 & 2.429 & .073 & 1.310 & 3.18 & The low rate of residents' incomes \\
\hline
\end{tabular}

Results shown in the paper illustrates that all the indicators have significance levels of less than 0.05 and their means are higher than normal (3) which means that economic indicators in old texture of district 15 are in an adverse situation.

Unsuitability of economic indicators slows down the process of optimization and renewal and reduces cooperation.

\subsection{Investigation of physical aspect in old texture of district 15}

In addition to indicators emphasized by ministry of road and urbanization, this study used other indicators which were different versions of main indicators. Results of assessment of physical aspect in old texture of district 15 are given in table 3.

Table 3: Measurement of physical aspect in old texture of district 15

\begin{tabular}{|l|l|l|l|l|l|l|l|}
\hline $\begin{array}{l}\text { Difference in level .95 of } \\
\text { certainty distance }\end{array}$ & $\begin{array}{l}\text { Mean } \\
\text { differences }\end{array}$ & $\begin{array}{l}\text { Significance } \\
\text { level }\end{array}$ & $\begin{array}{l}\text { t-test } \\
\text { statistics }\end{array}$ & $\begin{array}{l}\text { Mean of } \\
\text { standard } \\
\text { deviation }\end{array}$ & $\begin{array}{l}\text { Standard } \\
\text { deviation }\end{array}$ & Mean & Indicators \\
\hline The highest & The lowest
\end{tabular}




\begin{tabular}{|c|c|c|c|c|c|c|c|l|}
\hline .29 & -.02 & .134 & .011 & 1.665 & .080 & 1.442 & 3.13 & $\begin{array}{l}\text { Texture condition from aspects of renewal, } \\
\text { optimization, and destruction }\end{array}$ \\
\hline .34 & .02 & .181 & .009 & 2.199 & .082 & 1.472 & 3.18 & Existence of tall buildings in closed spaces \\
\hline .59 & .27 & .430 & .017 & 5.427 & .079 & 1.419 & 3.43 & Existence of buildings under construction \\
\hline .50 & .18 & .340 & .000 & 4.143 & .082 & 1.468 & 3.34 & Existence of abandoned and ruined buildings \\
\hline .35 & .03 & .190 & .000 & 2.268 & .084 & 1.501 & 3.19 & Improper applications (workshops, store,...) \\
\hline 1.01 & .76 & .882 & .000 & 13.730 & .064 & 1.150 & 3.88 & Dead end alleys \\
\hline 1.21 & .99 & 1.097 & .000 & 19.647 & .056 & 1.000 & 4.10 & Defenseless places \\
\hline
\end{tabular}

As with environmental and economic variables, one-sample t-test was adopted here, too. It shows that in addition to being significant, all the indicators are higher than normal which confirms the improper situation of old texture in district 15. This adverse situation affects other variables; for example unsuitable physical situation will cause a change in the attitudes of residents, leading them to emigrate from this district.

\subsection{Investigation of changing social variable in old texture of district 15}

This study analyzed four indicators to investigate the changing social variable from the viewpoints of residents. Table 4 is a result summary of this analysis.

Table 4: Assessment of changing social variable in old texture of district 15

\begin{tabular}{|c|c|c|l|l|l|l|l|l|l|}
\hline \multicolumn{2}{|l|}{$\begin{array}{l}\text { Difference in level } .95 \text { of } \\
\text { certainty distance }\end{array}$} & $\begin{array}{l}\text { Mean } \\
\text { differences }\end{array}$ & $\begin{array}{l}\text { Significance } \\
\text { level }\end{array}$ & $\begin{array}{l}\text { Degree of } \\
\text { freedom }\end{array}$ & $\begin{array}{l}\text { t-test } \\
\text { statistics }\end{array}$ & $\begin{array}{l}\text { Mean of standard } \\
\text { deviation }\end{array}$ & $\begin{array}{l}\text { Standard } \\
\text { deviation }\end{array}$ & Mean & Indicators \\
\hline The highest & The lowest & & -.003 & .015 & 383 & -.039 & .080 & 1.442 & 3.00 \\
\hline .16 & -.16 & $\begin{array}{l}\text { Population } \\
\text { density }\end{array}$ \\
\hline .50 & .18 & .340 & .002 & 383 & 4.143 & .082 & 1.468 & 3.34 & Immigration \\
\hline 1.21 & .99 & 1.097 & .000 & 383 & 19.647 & .056 & 1.000 & 4.10 & Poverty \\
\hline .90 & .59 & .741 & .000 & 383 & 9.338 & .079 & 1.423 & 3.74 & Emigration \\
\hline
\end{tabular}

Based on information given in this table, the significance levels for all the variables were less than 0.05 , therefore their significations are confirmed. Moreover, their means are above 3 which is a confirmation of adverse physical situation in the old texture.

\subsection{Investigation of changing managerial variable in old texture of district 15}

Three indicators are analyzed for the investigation of changing managerial variable in old texture of district 15.

Table 5: Assessment of changing managerial variable in old texture of district 15

\begin{tabular}{|l|c|c|c|c|c|c|c|c|}
\hline Indicators & Mean & $\begin{array}{l}\text { Standard } \\
\text { deviation }\end{array}$ & $\begin{array}{l}\text { Mean of } \\
\text { standard } \\
\text { deviation }\end{array}$ & $\begin{array}{l}\text { t-test } \\
\text { statistics }\end{array}$ & $\begin{array}{l}\text { Significance } \\
\text { level }\end{array}$ & $\begin{array}{l}\text { Mean } \\
\text { differences }\end{array}$ & $\begin{array}{l}\text { Difference in level .95 of } \\
\text { certainty distance }\end{array}$ \\
\hline $\begin{array}{l}\text { Lack of policy in urban management } \\
\text { in changes }\end{array}$ & 3.34 & 1.468 & .082 & 4.143 & .012 & .340 & .18 & .50 \\
\hline $\begin{array}{l}\text { Lack of mayoralty's action in changing } \\
\text { services }\end{array}$ & 3.19 & 1.501 & .084 & 2.268 & .003 & .190 & .03 & .35 \\
\hline $\begin{array}{l}\text { Lack of mayoralty's proper actions as } \\
\text { to civil projects in old textures }\end{array}$ & 3.88 & 1.150 & .064 & 13.730 & .017 & .882 & .76 & 1.01 \\
\hline
\end{tabular}

Results of one-sample t-test in the investigation of changing managerial situations show that indicators are significant and their means are above 3. Therefore, it can be stated that our first hypothesis ( $\mathrm{H} 1)$ is confirmed: managerial situation in old texture of district 15 is not in a good condition.

Finally, indicators related to each variable are mixed and total mean is calculated whose results are presented in table 6. 
Table 6: Assessment of the situation of different variables in old texture of district 15

\begin{tabular}{|c|c|c|c|c|c|c|c|c|}
\hline \multirow[t]{2}{*}{ Variable } & \multirow[t]{2}{*}{ Mean } & \multirow[t]{2}{*}{\begin{tabular}{|l} 
Standard \\
deviation
\end{tabular}} & \multicolumn{2}{|c|}{$\begin{array}{l}\text { Mean of standard } \\
\text { deviation }\end{array}$} & \multirow[t]{2}{*}{\begin{tabular}{|l} 
t-test \\
statistics
\end{tabular}} & \multirow[t]{2}{*}{$\begin{array}{l}\text { Significance } \\
\text { level }\end{array}$} & \multirow{2}{*}{\begin{tabular}{|l|}
$\begin{array}{l}\text { Mean of } \\
\text { differences }\end{array}$ \\
The lowest \\
\end{tabular}} & \multirow{2}{*}{\begin{tabular}{|l}
$\begin{array}{l}\text { Difference in level } .95 \text { of } \\
\text { certainty distance }\end{array}$ \\
The highest
\end{tabular}} \\
\hline & & & & & & & & \\
\hline Environmental & 3.09 & 1.602 & .089 & .975 & .000 & .087 & -.09 & .26 \\
\hline Economic & 3.15 & 1.286 & .072 & 2.126 & .000 & .153 & .01 & .29 \\
\hline Social & 3.18 & 1.310 & .073 & 2.429 & .000 & .178 & .03 & .32 \\
\hline Physical & 3.88 & 1.150 & .064 & 13.730 & .000 & .882 & .76 & 1.01 \\
\hline Managerial & 3.43 & 1.419 & .079 & 5.427 & .000 & .430 & .27 & .59 \\
\hline
\end{tabular}

Information provided in the above table illustrates that significance levels of all variables are less than 0.05 and their means are more than 3. Therefore, adverse situation of variables of old texture in district 15 is confirmed. Physical and environmental variables had the most and the least means, respectively.

\subsection{Investigation of the situation of social security}

Table 7: Assessment of social security indicators in old texture of district 15

\begin{tabular}{|c|c|c|c|c|c|c|c|c|}
\hline \multicolumn{2}{|c|}{$\begin{array}{l}\text { Difference in level .95 } \\
\text { of certainty distance }\end{array}$} & \multirow[t]{2}{*}{$\begin{array}{l}\text { Mean } \\
\text { differences }\end{array}$} & \multirow[t]{2}{*}{$\begin{array}{l}\text { Significance } \\
\text { level }\end{array}$} & \multirow[t]{2}{*}{ 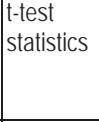 } & \multirow{2}{*}{$\begin{array}{l}\text { Mean of } \\
\text { standard } \\
\text { deviation }\end{array}$} & \multirow[t]{2}{*}{$\begin{array}{l}\text { Standard } \\
\text { deviation }\end{array}$} & \multirow[t]{2}{*}{ Mean } & \multirow[t]{2}{*}{ Indicators } \\
\hline $\begin{array}{c}\text { The } \\
\text { highest }\end{array}$ & $\begin{array}{l}\text { The } \\
\text { lowest }\end{array}$ & & & & & & & \\
\hline 1.87 & 1.26 & 1.567 & .000 & 10.500 & .149 & .817 & 4.57 & $\begin{array}{l}\text { Fear of walking through buildings under } \\
\text { constructions }\end{array}$ \\
\hline 1.92 & 1.22 & 1.567 & .031 & 9.175 & .171 & .935 & 4.57 & Fear of dead end alleys \\
\hline 1.81 & 1.26 & 1.533 & .007 & 11.50 & .133 & .730 & 4.53 & Fear of walking alone at nights \\
\hline 1.84 & 1.29 & 1.567 & .001 & 11.78 & .133 & .728 & 4.57 & $\begin{array}{l}\text { Fear of carrying much amount of cash } \\
\text { money }\end{array}$ \\
\hline 1.43 & .24 & .833 & .040 & 2.854 & .292 & 1.599 & 3.83 & Fear of leaving home \\
\hline 1.66 & .74 & 1.200 & .000 & 5.288 & .227 & .817 & 4.20 & $\begin{array}{l}\text { Fear of keeping shops open at late } \\
\text { night }\end{array}$ \\
\hline 1.80 & 1.07 & 1.433 & .000 & 8.082 & .177 & .935 & 4.43 & $\begin{array}{l}\text { Fear of getting on taxis with no any } \\
\text { other passengers }\end{array}$ \\
\hline 1.93 & 1.27 & 1.600 & .019 & 9.798 & .163 & .730 & 4.60 & Fear of sending children to school \\
\hline 1.63 & .64 & 1.133 & .018 & 4.660 & .243 & .728 & 4.13 & Fear of befriending strangers \\
\hline 1.81 & 1.06 & 1.433 & .000 & 7.802 & .184 & 1.599 & 4.43 & $\begin{array}{l}\text { Fear of parking cars unlocked and } \\
\text { without burglar alarm }\end{array}$ \\
\hline 1.77 & 1.03 & 1.400 & .000 & 7.642 & .183 & 1.243 & 4.40 & Fear of walking in empty paths \\
\hline 1.97 & 1.37 & 1.667 & .024 & 11.37 & .146 & .971 & 4.67 & Fear of walking in footbridges \\
\hline .89 & -.35 & .267 & .039 & .880 & .303 & .894 & 3.27 & Observing strife in the street \\
\hline .83 & -.36 & .233 & .000 & .804 & .290 & 1.332 & 3.23 & $\begin{array}{l}\text { Fear of carrying bag, cell phone, and } \\
\text { other valuable items }\end{array}$ \\
\hline 1.04 & .09 & .567 & .000 & 2.429 & .233 & 1.006 & 3.57 & Long distance to police station \\
\hline 1.15 & .18 & .667 & .000 & 2.819 & .237 & 1.003 & 3.67 & $\begin{array}{l}\text { Fear of populated areas in bazar or } \\
\text { squares }\end{array}$ \\
\hline 1.00 & -.07 & .467 & .000 & 1.785 & .261 & .802 & 3.47 & $\begin{array}{l}\text { Fear of going to bus stations and } \\
\text { subways }\end{array}$ \\
\hline 1.22 & .31 & .767 & .000 & 3.434 & .223 & 1.660 & 3.77 & Staying at home alone \\
\hline 1.16 & .17 & .667 & .000 & 2.763 & .241 & 1.591 & 3.67 & $\begin{array}{l}\text { Working place of couples and children } \\
\text { out of home }\end{array}$ \\
\hline 1.71 & 1.16 & 1.433 & .000 & 10.78 & .133 & 1.278 & 4.43 & Going out of women and daughters \\
\hline 1.33 & .27 & .800 & .000 & 3.077 & .260 & 1.295 & 3.80 & Jostling of passerby \\
\hline 1.41 & .32 & .867 & .015 & 3.261 & .266 & 1.432 & 3.87 & Seizure \\
\hline 1.33 & .33 & .833 & .003 & 3.403 & .245 & 1.223 & 3.83 & Blocking the ways \\
\hline 1.48 & .52 & 1.000 & .021 & 4.257 & .235 & 1.322 & 4.00 & $\begin{array}{l}\text { Interference of roadways and } \\
\text { pavements }\end{array}$ \\
\hline 1.31 & .49 & .900 & .000 & 4.506 & .200 & .728 & 3.90 & Drug dealing \\
\hline 1.12 & .15 & .633 & .000 & 2.670 & .237 & 1.424 & 3.63 & Sexual assault \\
\hline
\end{tabular}




\begin{tabular}{|l|l|l|l|l|l|l|l|l|}
\hline 1.23 & .37 & .800 & .002 & 3.788 & .211 & 1.456 & 3.80 & Commute of strangers \\
\hline 1.21 & .25 & .733 & .006 & 3.126 & .235 & 1.341 & 3.73 & Lacking suitable view \\
\hline 1.48 & .59 & 1.033 & .018 & 4.762 & .217 & 1.287 & 4.03 & Lacking proper lighting \\
\hline 1.46 & .54 & 1.000 & & 4.447 & .225 & 1.094 & 4.00 & Unobservable street signs \\
\hline
\end{tabular}

Overall, information given in the table shows that significance levels of all variables are less than 0.05 and their means are more than 3. Therefore, our first hypothesis is confirmed, i.e. residents believe that the old texture of district 15 does not enjoy a favorable social security.

Table 8: Results of T-test for the assessment of social security variable in the old texture of district 15

\begin{tabular}{|c|c|c|c|c|c|c|c|c|}
\hline \multirow[t]{2}{*}{ Indicator } & \multirow[t]{2}{*}{ Mean } & \multirow{2}{*}{$\begin{array}{l}\text { Standard } \\
\text { deviation }\end{array}$} & \multirow{2}{*}{$\begin{array}{l}\text { Mean of standard } \\
\text { deviation }\end{array}$} & \multirow[t]{2}{*}{ t-test statistics } & \multirow{2}{*}{$\begin{array}{l}\text { Degree of } \\
\text { freedom }\end{array}$} & \multirow{2}{*}{$\begin{array}{l}\text { Significance } \\
\text { level }\end{array}$} & \multicolumn{2}{|c|}{ Difference in level .95 of certainty distance } \\
\hline & & & & & & & The lowest & The highest \\
\hline Security & 3.34 & 1.468 & .082 & 4.143 & 383 & .002 & .18 & .50 \\
\hline
\end{tabular}

Based on these results, social security is a significant variable and its mean is more than normal showing that the situation of social security in the place in question is not good. This study continued with the investigation of the relationship between old texture and decreased social security using Pearson correlation coefficient whose results are summarized in table 9.

Findings of the study shows that there is a meaningful and significant relationship between the quality of old texture situation and decrease social security. Results of the questionnaires filled by residents of the old texture also show a significant and inverse relationship between old texture and social security. Significance level of less than 0.05 (alpha<0.05) shows a powerful and negative relationship between the two variables.

Table 9: Analysis of correlation of old texture and decreased social security

\begin{tabular}{|c|c|c|}
\hline Significance level & Correlation coefficient & Old texture \\
\hline $0 / 000$ & $-0 / 562$ & Decreased social security \\
\hline
\end{tabular}

\section{Conclusion}

Security has always been a major concern in human history and dates back to the concept of society. Expressional concept of security in its concrete aspect is the lack of threat against values governing in a society and in its abstract aspect, it means the sense of security. Feeling of security is equivalent to being safe or feeling of safety of one's life, properties, identity and values against threats and harms without being concerned about rational needs of the present and the future. In today world, in addition to lack of threat, the existence of favorable conditions for the realization of community goals and needs are considered in the definition of security. This view is based on a mental and interpretive attitude towards nonmaterial risks and emphasizes on software abilities and nonmaterial assets.

Feeling of security is a complex construct that despite having many definitions, there is not enough consensus about it. Such an important issue may have in-depth effect on social and economic lives of people. Security and insecurity in any society are affected by different factors. Weakening of social assets, inability of social control organizations, etc. strongly affect security and more importantly the feeling of security. In this study we investigated the factors affecting people's feelings of security in old textures of district 15 in Tehran. Providing social security and public discipline in communities is impossible without recognizing the factors affecting this feeling. Recognition of these factors and their effects in creating the feeling of social security is a necessary prerequisite in development of social security.

Old textures are not only a potential threat in case of natural disasters, but are also convenient places for increasing social delinquencies which may blemish the culture of residents. Drug dealing and consumption, gathering of addicts and traffickers and settlement of homeless people in ruined buildings compels responsible organizations to pay special attention to these districts. Police patrols usually arrest most homeless and delinquents in such corners, meaning that they are suitable places for gathering of such people.

Therefore, with regard to high rate of immigration to Tehran in recent decades giving it a different identity and texture with their different ethnicities and cultures, it is suggested that such districts will be equipped with needed infrastructures which are currently absent. Pinpointing crime-prone spots in residential areas and clearing them are another action which can develop the environment in which people are living. Moreover, the long distance between this 
district and police stations, it is necessary to establish police substations in these areas to increase the feeling of security. In other words, if the social relationships among residents of a district reach to a satisfactory degree and they be able to create a network of relationship, they can improve feeling of attachment to their society which in turn reduces fear of crimes.

The last point is that if the process of destruction in a district is prevented, delinquents and criminals are not led to think that such a district is good for delinquencies and that residents are not brave enough to defend themselves against assaults. If a district continues being ruined, criminals will be led to believe that they are free to do whatever they like without being stopped. Amendment physical elements reduced vulnerability signs. Adverse situations of different aspects of old textures (i.e. managerial, economic and physical aspects) not only affect criminals' attitudes but also is effective on the behavior of residents and their view of other citizens.

\section{Recommendations}

- Developing the performance of supervisory organizations (such police force) which are responsible for the regulation of people's relationships in a society with the aim of bringing back security to the city, districts, alleys, etc.

- Building trust is a way of strengthening the feeling of security.

- Planning for the reduction of social abnormalities and deviations in order to increase the feeling of security among residents.

- Establishing and developing civil organizations with the aim of increasing public cooperation and feeling of security

- Efforts in decreasing people's distrust to each other and to political and social organization.

- Development of cooperative and public actions for increasing safety and financial and social security

- Proper information giving to the public regarding threats and measures taken in order to decrease those threats for developing the feeling of social security.

- Refraining from spreading rumors which may disturb thoughts and increase nervousness

- Planning to strengthen familial relationships, increase trust and decrease separations.

- Providing enough lighting in the streets and pavements.

- Mayoralty control over buildings' design with the aim of creating the minimum hidden corners especially in ruined areas.

- Educating people and holding workshops and making them aware of suitable reactions when facing crimes and creating the sense of responsibility in them

\section{References}

Ahmadi, M. (2014). Security and environmental quality and life in the old textures (A case study of Imam Zadeh Yahya district). Nowsazi magazine, 4 (21).

Arsalani, Sh. \& Jibrail Vand, S. and Ghodusifar, H. (2015). Investigation of security and its role in social stability in historical texture of Ardabil, International conference on Stable City, Mobin Cultural Ambassador Organization, Tehran.

Afshari, M., Deilami, M. \& Tehrani, Gh. (2014). An analysis of factors affecting the security of general places: A case study of old texture in southern Shariati Street in Tabriz. The first conference on Geography, urbanization and stable development, Komesh society of environment, University of aerial industry, Tehran.

Chaharrahi, Z. (2006). Public cooperation and regional identity: a procedure to realize urban identity. The first national conference on urban improvement, Islamic Azad University, Sanandaj branch. Retrieved in 22.4.2013.

Hoseini, E. \& Adib Zadeh, B. (2009). Physical security with CPTED procedure, investigating environmental factors affecting creation of secure places in reconstruction of old textures: A case study of Nemat Abad old texture in district 19 of Tehran. Nowsazi magazine, $1(6)$.

Heidari, T. \& Yeganeh, M. (2014). Determining security in urban old textures based on parameter of space lighting: A case study of traditional bazar of Zanjan. The first conference on geography, urbanization and stable development.

Dejbord, Z. \& Montazarolhaj, M. (2015). Designing lost environmental spaces with an emphasis on developing social security in old textures: A case study of Masil Dowlat Abad in Yazd. The sixth conference on planning and urban management with an emphasis on elements of Islamic cities.

Shamai, A. \& Pur Ahmad, A. (2005). Urban optimization and reconstruction from a geographical point of view, Tehran University, Tehran.

Asgari, H., Adib Zadeh, B., Rafian, M. \& Hoseini, E. (2010). An analysis of environmental factors affecting reconstruction of urban old 
textures with the aim of developing security: A case study of Nemat Abad old texture in district 19 in Tehran. Urban Identity Magazinem, 4(6), pp.39-50.

Assarian, E. (2006). Cities: A reflection of discrimination against women. Sarmayeh Newspaper.

Attarinan, K., Hajian, F., Majidi, F. \& Izadi Far, V. (2014). Investigating the environmental factors affecting reconstruction of old textures with the aim of improving security in the region of Shanbadi in Bushehr. National conference on Architecture, urbanization and stable development with an emphasis on local architecture, Khavaran Institute, Mashhad.

Azimi, J., Owlad Zadeh, F. \& Mohammad Janlu, F. (2011). Developing urban safety and security in central texture of Sari. The first conference on Iranian Utopia, Islamic Azad University, Noor.

Alikhah, F. \& Najibi Rabiee, M. (2006). Women and fear of urban places. Social Welfare Quarterly, 5(22).

Fathi, M., Jahdi, N. \& Rauf, M. (2012). Determining the factors affecting the creation of secure urban places and development of physical security with CPTED procedure: A case study of Zabol traditional bazar. The conference on frontier cities and security: challenges and procedures.

Falahat, M. \& Rahim Zadeh, A. (2014). Reconstructing old city textures and developing the sense of security among citizens. National conference on urban architecture, culture and management, Scientific-practical center of Karaj Municipal, Karaj.

Gholi Pur, A. \& Seyedian, A. (2015). Developing security in old city textures with procedures of environmental designing: A case study of Sarhamam district in Babol. The national electronic conference on stable development in geography, planning, architecture and urbanization. The center for access to stable development.

Akbari, K. (2014). The role of reconstruction in the development of social control; effective guidelines for developing social identity, control and security in the reconstruction of old textures, Manzar Quarterly.

Kalani Nejad, M. \& Halime, H. (2012). The factors affecting created environment in urban regions with a view on environmental threats: A case study of BabaHazghil district in Dezful. The first national conference on geography, natural disasters and stable development.

Meshkini, A., Nowruzi, M. \& Moazzen, S. (2014). An analysis of environmental factors affecting the feeling of security in old textures: A case study of Fale Abkuh in Mashhad. The national conference on architecture and human-centered urbanization.

Yekani Fard, A., Ameri, H. \& Honarkhah, R. (2015). Assessment of satisfaction with life quality with an emphasis on social security in coastal cities: A case study of Bandar Abbas middle texture. The first conference on architecture and stable development in Iran.

Schweitzer, J. H. et.al.(1977)"The Impact of the Built Environment on Crime and Fear of Crime in Urban Neighborhoods", Journal of Urban Technology, Vol. 6, N.3 
